\title{
Erken Okuryazarlık Becerilerinin Ev Ortamında Desteklenmesi ${ }^{1}$
}

\author{
Sonnur IȘITAN* \\ Mesut SAÇES ${ }^{* *}$ \\ Kazım BiBER ${ }^{* * *}$
}

\begin{abstract}
Öz: Sesli kitap okuma etkinlikleri çocukların okuma ve yazma becerilerinin gelişiminde ve ilerleyen yıllardaki okuma başarıları üzerinde etkilidir. Bu çalı̧̧mada ebeveynlerin evde çocuklarına düzenli kitap okumalarının çocuklarının yazı farkındalıkları üzerindeki etkisini incelemek amaçlanmıştır. Araştırmanın örneklemini Balıkesir il merkezinde yaşayan orta sosyo-ekonomik düzeydeki uygun örnekleme yolu ile seçilmiş okul öncesi çağda 20 çocuk (7 erkek, $13 \mathrm{kız}$ ) ve anneleri oluşturmaktadır. Araştırmada tek grup ön test - son test deney öncesi desen kullanılmıştır. Çalışma grubundaki çocuklara ön test ve son test olarak “Erken Çocukluk Dönemi Yazı Farkındalı̆̆ı Kontrol Listesi” uygulanmıştır. Çalışmada kitap okuma teknikleri konusunda bir eğitim verilmeksizin annelerden toplam 8 adet resimli kitabı haftada iki kez okumaları istenmiştir. Araştırma sonucunda annelerin ev ortamında çocuklarına sadece düzenli (nitelikli çocuk kitabı ile) kitap okuduğunda bile çocukların yazı farkındalığı becerilerinde artış olduğu saptanmıştır. Ebeveynlere yönelik farklı okuma tekniklerine ilişkin eğitim programlarının çocukların erken okuryazarlık becerilerine etkisini inceleyen deneysel çalışmalar yapılması önerilmektedir.
\end{abstract}

Anahtar Sözcükler: Sesli Okuma, Erken Okuryazarlık, Ev Okuryazarlık Ortamı, Yazı Farkındalı̆̆ı, Okul Öncesi Dönem

\section{Supporting Children's Early Literacy Development at Home}

\begin{abstract}
Reading aloud to children has been linked to young children's development of reading and writing skills and children's later success in reading. In this study, it was aimed to investigate the effect of parents' book reading on children's print awareness skills without providing any information or training to the parents about story book reading. The convenience sample of the study consisted of 20 preschoolers ( 7 boys and 13 girls) and their mothers all from middle socioeconomic status in Balıkesir Province. In the present study, one group pretest-posttest pre-experimental design was used. "Early Childhood Print Awareness Checklist" was used to assess children's print awareness skills in pre- and post-test. Mothers were asked to read a total of 8 picture story books twice a week. The results demonstrated that regularly reading quality picture story books at home, even without a training to do so, increase children's print awareness skills. Experimental studies focusing on the effects of training programs about different reading techniques provided parents on their children's early literacy skills were suggested.
\end{abstract}

Keywords: Read Aloud, Early Literacy, Home Literacy, Print Awareness, Preschool Period \\ ${ }^{1}$ Bu çalışma, Balıkesir Üniversitesi tarafından desteklenmiştir. BAP Proje No: 2016/0046 \\ * Balıkesir Üniversitesi, Necatibey Eğitim Fakültesi, Temel Eğitim Bölümü, Balıkesir, Türkiye, e-posta:sonnurisitan@balikesir.edu.tr, \\ ORCID: https://orcid.org/0000-0002-1998-0446 \\ ** Balıkesir Üniversitesi, Necatibey Eğitim Fakültesi, Temel Eğitim Bölümü, Balıkesir, Türkiye, e-posta:msackes@balikesir.edu.tr, \\ ORCID: https://orcid.org/0000-0003-3673-1668 \\ *** Balıkesir Üniversitesi, Necatibey Eğitim Fakültesi, Temel Eğitim Bölümü, Balıkesir, Türkiye, e-posta:kbiber@balikesir.edu.tr, \\ ORCID: https://orcid.org/0000-0001-8706-4733
}


Okuryazarlık doğumla başlayan ve okul öncesi dönemde gelişerek devam eden bir süreçtir. Çocuğun sözel dil ve yazılı formu öğrenmesinde okul öncesi dönem büyük önem taşımaktadır (Rosenkoetter ve Barton 2002). Çocuklara okul öncesi dönemde sesli kitap okunması, alıcı ve ifade edici dil becerilerini geliştirdiği gibi erken okuryazarlık ve ilkokula hazırlık becerilerini de desteklemektedir (Ezell ve Justice, 2005; Snow, Burns ve Griffin, 1998; Storch ve Whitehurst, 2001). Kitap okuma uygulamaları sayesinde çocuklar; kitabı nasıl tutması gerektiğini, okumaya nereden başlandığını öğrenmekte, okuma sırasında seslerin sembolü olan harfleri tanımakta, harflerin biraya gelerek sözcükleri oluşturduğunu anlayıp, sözcüklerin anlamlarını kavramaktadır (Vivas, 1996).

Alan yazında çocuklara yönelik yürütülen okuma uygulamaları çalışmalarında farklı terimler karşımıza çıkmaktadır. Paylaşımlı okuma (shared reading), terimini ilk kez, kendi araştırmasına dayanarak Holdaway (1979) kullanmıştır (akt. Schickedanz ve McGee, 2010). Holdaway paylaşımlı kitap okumayı; okuma yazma eğitimine yeni başlayan çocukları desteklemek için kullanılan okuma tekniği olarak tanımlamıştır. Buna göre okuma yazma eğitimine başlayan çocukların genişletilmiş metinleri olan kitapları okumaları sırasında, örneğin birebir metin izleme ve harf-ses ilişkilerini öğrenme gibi, okuma yazmayı öğretmek için kullanılan bir model olarak tanımlamıştır (akt. Schickedanz ve McGee, 2010). Diğer bir kavram ise "sesli okuma"dır (reading aloud). Sesli okuma çocuklara uygun tonda sesli kitap okumayı ifade etmektedir. Schickedanz ve McGee (2010) sesli okumayı çocuklara etkileşimli bir şekilde kitap okuyarak çocukların dil gelişimini, dinleme becerilerini ve yazı farkındalığı becerilerini destekleyen okuma eylemi olarak tanımlamışlardır. Sesli kitap okuma etkinliklerinin çocukların okuma ve yazma becerilerinin gelişiminde ve ilerleyen yıllardaki okuma başarıları üzerinde etkili olduğunu ortaya koyan çalışmalar (Lonigan, 2004; Whitehurst ve Lonigan, 2001) bulunmaktadır. Bu çalışmalar aynı zamanda sesli kitap okumanın çocukların yazı kavramını, öykü yapısını ve metindeki diğer bileşenleri kavramasını ve yazının işlevine ait geniş bilgiler edinmesine imkan tanıyabildiğini de göstermektedir. Ayrıca çocuklara yönelik düzenli kitap okuma etkinlikleri çocukların kelime haznelerini geliştirmekte, onlara yeni sözcükler kazandırmaktadır (De Temple ve Snow, 2003). Morrow ve Gambrell (2002) çocuklara düzenli kitap okunmasının dinleme ve dinlediği hikayeyi kavrama becerilerini desteklediğini belirtmektedir. Wigfield ve Guthri (1997) kitap okuma için ayrılan sürenin de önemli olduğuna dikkat çekerek, çocuklara fazla kitap okunmasının onların okuma başarısı, sözcük bilgisi ve toplumsal becerileri üzerinde önemli ölçüde katkıda bulunduğunu işaret etmektedirler. Chomsky (1972) çocuğun kitaplara maruz kalması ile dil gelişimi arasında pozitif bir ilişki bulmuştur. Bununla birlikte çocuklara kitap okumak çocukların dilin biçim boyutuna ilişkin anlayışlarını desteklemekte ve söz dizimi kurallarını anlamalarını sağlamaktadır (Chomsky, 1972).

Yukarıda bahsedilen çalışmalardan da anlaşılabileceği gibi erken okuryazarlık becerilerini okul öncesi dönemde desteklemede çocuklara sesli kitap okuma en önemli etkinliklerden biridir. Sesli kitap okuma çocukların erken akademik becerileri destekleyen önemli tekniklerden biridir. Erken akademik becerileri DeLaCova (2003), Florida İlkokula Hazırlık Performansı Standartlarına göre (2002) şu şekilde tanımlandığını belirtmiştir; erken okuryazarlık becerileri kelime dağarcığı, yazı bilinci, ses bilgisi, ses bilgisel farkındalığı, harf bilgisi, hikaye kavrama ve ilkokul dönemindeki okuma yazma kazanımlarından oluşmaktadır. Morrow ve Gambrell (2002) okul öncesi dönemde en önemli okuma yazmaya hazırlık becerisinin hem evde hem de okul ortamında çocuklara kitap okuma olduğunu belirterek, sadece okul ortamı değil ev ortamının da okuma yazmaya hazırlık becerilerinin kazandırılmasının önemli olduğunu vurgulamaktadır. Bu sebeple erken okuryazarlık becerileri sadece okul ortamında değil ev ortamında da desteklenmelidir. Ebeveynlerin çocuklarına kitap okumaları özellikle çocukların dil gelişimi üzerinde etkili olmaktadır (Polat Unutkan, 2006). Yine Roberts, Jurgens ve Burchinal (2005), ev okuryazarlık ortamı ile okuryazarlık becerilerinden olan alıcı ve ifade edici dil, sözcükleri anlama ve okuma becerileri arasında doğrusal bir ilişki olduğunu bulmuşlardır.

Burgess, Hecht ve Lonigan (2002) erken okuryazarlık becerileri okul öncesi dönemde özellikle 3-5 yaşları arasında gelişmeye başladığından evde gerçekleşen paylaşımlı/birlikte okuma etkinliklerinin çocukların okuma ve dil gelişimlerini etkilediğini saptamışlardır. Öte yandan Bus, Van Ijzendoorn ve Pellegrini (1995), yaşamın ilk altı yılında paylaşımlı kitap okuma olarak da adlandırılan ebeveynlerin çocuklarıyla birlikte 
hikaye kitabı okumasının çocukların dil gelişimleri, okuryazarlık becerileri ve ilerideki okuma başarıları gibi akademik becerileri ile ilişkili olduğunu belirtmişlerdir.

Okul öncesi dönemde erken okuryazarlık becerilerinin desteklenmesi için öncelikle ebeveynlerin ev ortamını erken okuryazarlık açısından destekler nitelikte düzenlemeleri gerekmektedir (Lopez, 2005; Whitehurst, Arnold, Epstein ve Angell, 1994; Zeece ve Wallace, 2009). Erken okuryazarlığı destekleyen ev ortamı kitap okuma etkinliklerini, sözcüklerin anlamını öğretme ve yazı farkındalığını destekleme uygulamalarını kapsamaktadır. Ancak çoğu ebeveyn okul öncesi dönemde bu uygulamaların öneminin farkında değildir (Whitehurst ve diğerleri, 1994). Rosenkoetter ve Barton (2002) ailelerin bebeklerine ve/veya çocuklarına kitap okuyarak onların daha sonraki akademik başarıları destekleyebileceklerini belirtmektedirler. Bununla birlikte okuryazarlık becerilerinin çocukların akademik başarıları için gerekli olduğunu ve bu becerilerin de yazı bilinci, farkındalığı, çocukların dil deneyimleri, dil açısından model olunması, okuma yazma motivasyonları, okuma yazma materyalleri ile sesler, bağlam içinde kullanılmayan dil örüntüleri ve yazma ile ilgili deneyimler olduğundan bahsetmişledir (Rosenkoetter ve Barton, 2002). Hammer, Nimmo, Cohen, Clemons ve Achenbach (2005) anneler ile yaptıkları çalışmada Porto Rican Head Start okuluna devam eden çocukların annelerinin çocuklarına kitap okuma davranışlarını gözlemlemişlerdir. Buna göre annelerin okuma sırasında kitabın resimleri ve kitapta geçen öykü hakkında çok fazla konuşmadıklarını, kitap hakkında, yazı bilgisi, okuma süreci ve harf farkındalığı hakkında sınırlı ölçüde bilgi verdiklerini belirtmişlerdir. Vivas (1996) yaptığı çalışmada 222 okul öncesi ve birinci sınıf çocuğu için, sistematik hikaye okuma ve sesli kitap okuma programının bazı dil değişkenleri üzerindeki etkilerini deneysel olarak araştırmıştır. Buna göre ebeveynler ikisi deneysel biri kontrol grubu olmak üzere rastgele 3 gruba ayırılmışlardır. Program, ebeveynler tarafından evde (Ev Tabanlı Deneysel gruptaki çocuklar için) ve öğretmen tarafından okulda (Okul Tabanlı Deneysel çocuklar için) uygulanmıştır. Kontrol grubuna ise bir program uygulanmamıştır. Araştırmada kitap okumanın çocukların dili kavrama (sözdizimi yapıları ve hikayeyi anlama) ve ifade edici dil (sözdizimi yapısı ve cümle tekrarı) becerileri üzerindeki etkileri incelenmiştir. Sonuçlar hem okul öncesi hem de birinci sınıf çocuklarının, evde veya okulda, yüksek sesle okunan hikayeleri dinlemelerinin onların dili anlama ve ifade etme becerilerini önemli ölçüde arttırdığı gözlenmiştir.

Alan yazında ev ortamında çocukların erken okuryazarlık becerilerini desteklemesinin yanı sıra aile özelliklerinin de etkileri üzerinde durulmuştur. Sosyo-ekonomik düzeyi düşük olan ve farklı kültürlerdeki aile ve onların çocuklarıyla yapılan araştırmalar, bu grupta yer alan çocukların erken okuryazarlık becerilerinde önemli ölçüde desteğe ihtiyaç duyduklarını göstermektedir. Smith ve Dixon (1995) da çalışmalarında, sosyo-ekonomik düzeyleri düşük veya orta olan ailelerinin dört yaşındaki çocuklarının okuryazarlık bilgilerini karşılaştırmıştır. Bunun için okul öncesi dönemde çocukları olan ebeveynlerin çocukları ile oluşturdukları okuryazarlık deneyimlerini incelemişlerdir. Araştırma sonuçlarına göre, sosyoekonomik düzeyleri orta olan ebeveynlerin \%74'ü her gün çocuklarına kitap okumakta iken; düşük gelirli ebeveynler çocuklarına haftada bir defadan fazla kitap okumamaktadırlar. Düşük sosyo-ekonomik düzeydeki ebeveynlerin \%39'u çocuklarına "çok nadir" ve "arada sırada" kitap okuduklarını, ayrıca orta sosyo-ekonomik düzeydeki ebeveynlere nazaran çok daha az okuma etkinliği gerçekleştirdiklerini ifade etmişlerdir. Yoksul ailelerin kütüphaneye gitme, çocuklarına resim yapma, çizim yapma ve gazete ve dergi okuma gibi etkinlikleri daha az gerçekleştirdikleri sonucuna ulaşılmıştır. Rodriguez ve diğerleri (2009) düşük gelirli ailelerin çocukları ( $n=1046)$ ile uzunlamasına yaptıkları araştırmada, çocukların ilk üç yılında dil ve okuryazarlık ortamlarına odaklanmışlardır. Çocukların dil ve bilişsel yetenekleri okuryazarlık faaliyetlerine katılım sıklığı, annelerin çocuklarıyla ilişkilerinin kalitesi ve yaşa uygun öğrenme materyallerinin sağlanması ile ilişkisi çocuklar 14, 24 ve 36 aylıkken incelenmiştir. Çalışma sonucunda çocuk ve aile özelliklerinin ötesinde okuryazarlık ortamının her yaşta çocuğun dil ve bilişsel becerilerinin öngörülmesini sağlayan önemli değişken olduğu saptanmıştır. Weigel, Martin ve Bennett (2006) yaptıkları çalışmada ebeveynlerin okuma yazma alışkanlıkları ile onların okuma inançları, okuma inançları ile evdeki ebeveyn-çocuk okuryazarlığı ve dil etkinlikleri, ebeveyn-çocuk okuryazarlığı ve dil etkinlikleri ile çocukların yazı farkındalıkları ve okuma ilgileri arasında pozitif ilişki olduğunu bulmuşlardır. Needlman, Fried, Morley, Taylor ve Zuckerman (1991) yaptıkları çalışmada "Reach out and read-ROR (Ulaş ve oku)" programlarının ulusal örneklemde etkisini 
incelemişlerdir. Programın en büyük çalışması uygun örnekleme olarak 10 eyalette 19 klinik bölgede rutin sağlık hizmetine başvuran 6-72 aylık çocukların ebeveynleri ile yapılan çalışmadır. Örneklem 1647 (730 müdahale, 917 karşılaştırma) ebeveynden oluşmuştur. Ebeveynlerle geçerli ve güvenilir araçlardaki sorular kullanılarak sesli okuma ile ilgili tutum ve uygulamaları hakkında görüşülmüştür. Bağımsız değişkenler kontrol edildikten sonra sesli kitap okumanın en sevilen ebeveynlik etkinliği olduğu ortaya çıkmıştır (Needlman, Toker, Dreyer, Klass ve Mendelsohn, 2005). ABD'de önemli bir uygulama olan ROR programı yine ailelerin çocuklarına düzenli kitap okumalarının etkilerine odaklanmıştır. ROR modeli, 6 ay - 5 yaş aralığında olan çocukların sağlık kontrolü ziyaretlerinde ebeveynlere ücretsiz resimli kitapların dağıtımı ile sesli kitap okuma ve bu konudaki rehberliği içermektedir (Needlman ve diğerleri, 2005). ROR Programının genel olarak çocukların dil becerileri üzerinde olumlu etkileri olduğu, çocukların dil becerilerini desteklediği saptanmıştır (Sharif, Reiber ve Ozuah, 2002).

Alan yazında ebeveynlerin demografik özellikleri, çocukların ifade edici ve alıcı dil becerileri ile ilişkilendirilmiştir. Hammer, Miccio ve Wagstaff (2003), ebeveynlerin çocuklarına kitap okumalarının ve çocuklarını okumaya teşvik etmelerinin okuryazarlığa verdikleri değeri gösterdiğini öne sürmüşlerdir. Ebeveynler çocuklarının erken okuryazarlık becerilerini desteklediklerinde, okuma ilgilerine cevap verdiklerinde, kendilerini çocuklarının akademik başarılarına katkı sağladıklarını hissettiklerini belirtmiştir. Yapılan araştırmalar ebeveynlerin çocuklarına kitap okumalarının onların akademik becerilerine olumlu etkisi dışında ebeveynler ve çocuklar arasında olumlu etkileşim sağladığını da göstermektedir. Bu etkileşimlerin özellikle ebeveynlerin çocuklarına okuma sırasında yeni sözcüklerin anlamlarını söylemelerinin çocukların sözcük bilgisini geliştirdiği saptanmıştır (Coyne, McCoach ve Kapp, 2007).

Ülkemizde konu ile ilgili yapılan çalışmalarda ebeveynlerin çocuklarına çok fazla kitap okumadıkları, ebeveynlerin öğrenim düzeyi arttıkça çocukları ile daha fazla vakit geçirerek akademik becerilerini destekledikleri bulunmuştur (Arıcı ve Tüfekci Akcan, 2019; Kotaman, 2008; Okuyucu-Akdaş ve Deniz, 2015; Özbek Ayaz, Güleç ve Şahin, 2017). Işıkoğlu-Erdoğan ve diğerleri (2016) öğretmenlerin konu hakkında bilgi düzeylerinin yüksek olması nedeniyle öğretmenlerin ailelere nazaran çocuklara daha fazla kitap okuduğunu bulmuşlardır. Ancak Altıparmak (2010), ebeveynlerin çoğunluğunun ev ortamında gerçekleştirilen erken okuryazarlık etkinliklerinin çocuklarının erken okuryazarlık becerilerinin gelişimi için önemli olduğuna inandıklarını ve planlı-yapılandırılmış etkinliklere ebeveynlerin daha fazla önem verdiklerini belirlemiştir.

Okul öncesi çağdaki çocuklarda erken okuryazarlık becerilerini geliştirmek için nitelikli ev-okul işbirliğini sağlamak gerekmektedir. Ev-okul işbirliği özellikle çocukların ileriki dönemlerde okuma yazma eğitiminde destekleyici bir öğedir. Çocuklara okunan kitapların niteliği de oldukça önemlidir. Başarılı kitap okuma etkinlikleri için nitelikli çocuk kitaplarına (çocukların yaş ve gelişimlerine uygun, ilgi duydukları konularda) ihtiyaç duyulmaktadır (McNair, 2011). Bu sebeple nitelikli kitapları ailelere ulaştırmak, ailelerin çocuklarına evde çocuklarına kitap okumalarını sağlamak, çocukların erken okuryazarlık becerilerini desteklemelerini sağlamak çocukların ileriki yıllarda sahip olmaları gereken en temel akademik becerilerden biri olan okuma yazma becerilerini destekleyecektir. Bu becerilerin desteklenmesi, çocuklarda okuma yazma başarısızlığını azaltmak ve çocuklardaki akademik başarıyı arttırmak açısından büyük önem taşımaktadır.

Ülkemizde ev ortamında erken okuryazarlık becerilerinin desteklenmesine yönelik olarak genellikle ailelere eğitim vererek etkileşimli kitap okuma (Çelebi Öncü, 2016), ev ortamında ailelerin çocuklarına nasıl kitap okuduğu (Arıcı ve Tüfekci Akcan, 2019; Işıkoğlu Erdoğan, 2016; Işıkoğlu Erdoğan ve diğerleri, 2016, Özbek Ayaz, 2015), annelerin çocuklarına kitap okurken kullandıkları dil (Cengiz, 2013), anne-babaların erken okuryazarlık becerileri hakkındaki farkındalık düzeyleri (Altıparmak, 2010; Turan ve Akoğlu, 2014) ve çocuklarının ses bilgisel farkındalık becerileri ile arasındaki ilişki (Turan ve Akoğlu, 2014), ev okuryazarlık ortamının ailelerin sosyo-ekonomik düzeyine göre incelenmesi (Ergül, Sarıca, Akoğlu ve Karaman, 2017; Okuyucu-Akdaş ve Deniz, 2015) gibi çalışmalar bulunmaktadır. Bununla birlikte alan yazında ailelere nitelikli kitaplar sağlayarak çocuklara ev ortamında düzenli kitap okumanın çocukların erken okuryazarlık becerileri üzerinde ne gibi etkileri olduğuna dair çalışmaya rastlanmamaktadır. Bu sebeple bu çalışmanın alan yazına katkı sağlayacağı düşünülmektedir. 


\section{Araştırmanın Amacı}

$\mathrm{Bu}$ çalışmada ev temelli aile okuma uygulamasının çocukların yazı farkındalıkları üzerindeki etkisini incelemek amaçlanmıştır. Bu çalışmada kitap okuma teknikleri konusunda hiç eğitim ve bilgilendirme almayan ailelerin sadece düzenli olarak nitelikli kitap okuma etkinliği ile çocuklarının erken okuryazarlık becerilerini ne derecede destekleyebileceğinin incelenmesi amaçlanmıştır.

\section{Yöntem}

\section{Araştırma Deseni}

Bu araştırmada ev temelli aile okuma uygulamasının çocukların erken yazı farkındalığı üzerindeki etkisini incelemek amacıyla tek grup ön test - son test deney öncesi desen kullanılmıştır (Cook ve Campbell, 1979).

\section{Çalışma Grubu}

Araştırmanın örneklemini Balıkesir il merkezinde yaşayan ve çalışmaya gönüllü olarak katılmak isteyen orta sosyo-ekonomik düzeydeki uygun örnekleme yolu ile seçilmiş okul öncesi çağda 20 çocuk (7 erkek, 13 kız) ve anneleri oluşturmaktadır. Çalışma için ebeveynler ile görüşülmüş ve anneler çalışmaya gönüllü katılmışlar ve araştırma izin formunu imzalamışlardır. Çalışmaya katılan annelerin yaş ortalaması $34.4 \pm 4.9$ ve çocukların yaş ortalaması $54.0 \pm 11.7$ aydır. Çocukların 15'i okul öncesi eğitim almakta, 5'i okul öncesi eğitim almamaktadır. Annelerin öğrenim düzeyi Tablo 1'de verilmiştir.

Tablo I

Annelerin Öğrenim Düzeyi

\begin{tabular}{lll}
\hline Öğrenim düzeyi & $F$ & $\%$ \\
\hline İlkokul & 2 & 10.0 \\
Ortaokul & 2 & 10.0 \\
Lise & 3 & 15.0 \\
Önlisans & 4 & 20.0 \\
Lisans & 9 & 45.0 \\
\hline Toplam & 20 & 100.0 \\
\hline
\end{tabular}

Tablo 1'de görüldüğü gibi annelerin \% 45'i lisans, \%20'si ön lisans, \% 15'i lise ve \% 10'u ilkokul ve \% 10'u da ortaokul mezunudur. Tablo 2'de ise annelerin kitap okuma sıklığı görülmektedir.

Tablo II

Annelerin Kitap Okuma Sıklı̆̆ı

\begin{tabular}{llc}
\hline Kitap okuma siklığ1 & $\mathrm{N}$ & $\%$ \\
\hline Her gün & 10 & 50.0 \\
Haftada bir & 5 & 25.0 \\
Y1lda bir kez & 4 & 20.0 \\
Okumuyorum & 1 & 5.0 \\
\hline Toplam & 20 & 100.0 \\
\hline
\end{tabular}

\section{Veri Toplama Araçları}

Aile bilgi formu. Veri toplama aracı olarak öncelikle ailelerin demografik bilgilerinin olduğu "Aile Bilgi Formu" kullanılmıştır. Bu form anneler ile yüz yüze görüşülerek araştırmacılar tarafından doldurulmuştur.

Erken çocukluk dönemi yazı farkındalığı kontrol listesi. Çalışma grubundaki çocuklara ön test ve son test uygulaması olarak yazı farkındalığı becerilerini değerlendirmek amacıyla Işıtan ve Akoğlu (2016) tarafından geliştirilen "Erken Çocukluk Dönemi Yazı Farkındalığı Kontrol Listesi” kullanılmıştır. Araç, araştırmacılar tarafından 48 - 72 aylık çocukların yazı farkındalığı becerilerini değerlendirmek amacıyla geliştirilmiştir. Araç toplam 33 maddeden oluşmakta ve uygulama sırasında Bilgin Adalı tarafından yazılan "Arkadaşım Papi" isimli resimli öykü kitabı kullanılarak çocukların yazı farkındalığı becerileri değerlendirilmektedir (Adalı, 2011). Aracın güvenirliğinin saptanması için Kuder-Richardson 20 formülü kullanılmıştır ve iç tutarlılık güvenirlik katsayıları kitap ve yazı düzeni bölümü için (20 madde) .74, sözcükler bölümü için (10 madde) .76, harfler bölümü için (3 madde) .62'dir. Aracın diğer bölümünde çocukların kalem tutma ve harf çizim 
becerilerine bakılmaktadır.

Okuma kayıt formu. Annelerden çocuklarına kitap okuduktan sonra okuma bilgilerini kaydedecekleri "Okuma Kayıt Formu" nu doldurmaları istenmiştir. Bu formda kitabın okunduğu tarih, kitap okuma sayısı, kitap okuma süresi ve genel görüşlerin yazılacağı bölümler bulunmaktadır.

Resimli kitaplar. Resimli kitaplar araştırmacılar tarafından alan yazında önerilen ölçütler temelinde seçilmiştir. Kitapların seçiminde kullanılan ölçütler şunlardır: (1) Çocukların yaş ve gelişimine uygun, ilgi duydukları kitaplar, (2) Yazı farkındalığını destekleyen kitaplar, (3) Aşina olunmayan kitaplar. Bu ölçütler kullanılarak 100'ün üzerinde resimli kitap incelenmiş tüm ölçütleri karşılayan 8 resimli kitap bu çalışma uygulaması için seçilmiştir.

\section{Deneysel Uygulama İşlemi}

Çalışmada anneler ile yüz yüze görüşülüp araştırmanın amacı açıklanmıştır. Anneler aile bilgi formu doldurmuştur. Ön test olarak “Erken Çocukluk Dönemi Yazı Farkındalığı Kontrol Listesi” çocuklara sessiz ve çocukların rahat olduğu ev ortamında uygulanmıştır. Annelerden toplam 8 adet resimli kitap okumaları istenmiştir. Daha sonra annelere önce 4 kitap verilmiştir. Annelerden bu kitapları istenen sırasıyla haftada 2 kez okumaları istenmiştir. Dördüncü haftada annelerle tekrar görüşülmüş, uygulama hakkında genel bilgi alınmış ve diğer 4 kitap verilmiştir. Aynı şekilde annelerin çocuklarına düzenli olarak diğer kitapları okumaları istenmiştir. Anneler okuma tarih ve saatlerini, sürelerini “Okuma Kayıt Formu” na kaydetmişlerdir. Sekizinci hafta sonunda anneler okuma işlemini tamamladığında son test uygulaması yapılmıştır. Annelere kitap okuma yöntemiyle ilgili hiçbir eğitim verilmemiştir. Sadece verilen kitapları çocuklarına okumaları istenmiştir. Bu çalışmada hiç eğitim verilmeden sadece düzenli kitap okuma etkinliğinin çocuk üzerindeki etkisini belirlemek amaçlanmıştır.

\section{Veri Analizi}

Ev temelli aile okuma uygulamasının çocukların erken yazı farkındalığı üzerindeki etkisini incelemek amacıyla yapılan bu araştırma kapsamında toplanan verilerin analizinde betimsel istatistikler, bağımlı örneklem T-Testi ve Wilcoxon testi kullanılmıştır. Veriler SPSS 24 paket programı kullanılarak çözümlenmiştir.

\section{Bulgular}

Ev temelli aile okuma uygulamasının çocukların yazı farkındalıkları üzerindeki etkisini incelemek amacıyla yürütülen bu çalışmada, kitap okuma uygulama öncesi ve sonrasında uygulanan "Erken Çocukluk Dönemi Yazı Farkındalığı Kontrol Listesi" nin tüm alt boyutlarında ön testten son teste çocukların puanlarında bir artış olduğu gözlenmiştir. Bulgular Tablo 3'te sunulmuştur.

\section{Tablo III}

Örneklemi Oluşturan Çocukların Ön Test ve Son Test Puanları

\begin{tabular}{lccccc}
\hline \multicolumn{1}{c}{ Boyut } & Ölçüm & Ortalama & $\mathrm{n}$ & Std. Sapma & Ort. Std. Hata \\
\hline \multirow{2}{*}{ Kitap ve yazı düzeni } & Ön test & 13,2000 & 20 & 3,22164 &, 72038 \\
& Son test & 14,6000 & 20 & 3,25091 &, 72693 \\
Yazı bilgisi & Ön test & 1,6000 & 20 & 1,04630 &, 23396 \\
& Son test & 1,8000 & 20 & 1,00525 &, 22478 \\
Harfler & Ön test & 3,3000 & 20 & 1,78001 &, 39802 \\
& Son test & 3,7500 & 20 & 1,58529 &, 35448 \\
Sözcükler & Ön test & 1,3500 & 20 & 1,75544 &, 39253 \\
& Son test & 2,8500 & 20 & 2,00722 & 1,57597 \\
Genel Toplam & Ön test & 18,9000 & 20 & 7,04796 & 1,23884 \\
& Son test & 22,8000 & 20 & 5,54028 & \\
\hline
\end{tabular}


Tablo 3'te çocukların ön testten son teste puanlarda gözlenen değişimin istatistiksel olarak anlamlı olup olmadığı kitap ve yazı düzeni, harfler, sözcükler ve genel toplam boyutları için bağımlı örneklem t-testi ile incelenmiştir. Normallik varsayımının karşılanmadığı yazı boyutunun verileri ise Wilcoxon testi ile incelenmiştir. Sonuçlar "Kitap ve yazı düzeni" ( $\mathrm{t}=1.85, \mathrm{df}=19, p=0.08)$, "Harfler" ( $\mathrm{t}=1.69, \mathrm{df}=19, p=0.11)$ ve "Yazı" ( $\mathrm{Z}=1.63, p=0.10)$ boyutlarında gözlenen puan artışının istatistiksel olarak anlamlı olmadığını, buna karşın "Sözcük" boyutu puanları $(\mathrm{t}=3.38, \mathrm{df}=19, p=0.003)$ ve Genel toplam ( $\mathrm{t}=3.43, \mathrm{df}=19, p=0.003)$ puanlarındaki artışın istatistiksel olarak anlamlı olduğunu göstermiştir. İstatistiksel olarak anlamlı bulunan "Sözcük" boyutu (d=0.81, \% 95 GA:0.17-1.46) ve Genel Toplam (d=0.71, \% 95 GA:0.08-1.35) puanlarındaki artış için hesaplanan etki büyüklüğü orta etkinin üstünde bulunmuştur. Araştırma sonucuna göre nitelikli resimli kitaplar çocuklara düzenli şekilde okunduğunda çocukların kitaptaki sözcükleri fark ettikleri, sözcükler hakkındaki farkındalıklarının arttığı bulunmuştur. Başka bir deyişle uygulanan okuma uygulamasının çocukların yazı farkındalıklarının ölçülen boyutlarında yaklaşık bir standart sapmalık artışa neden olduğu gözlenmiştir.

\section{Sonuç ve Tartışma}

Bu çalışmada ev ortamında annelerin okul öncesi dönemde bulunan çocuklarına düzenli kitap okumalarının çocuklarının yazı farkındalıkları üzerindeki etkisi incelenmiştir. Bu kapsamda çalışmaya katılan annelere kitap okuma teknikleri konusunda hiçbir eğitim verilmemiş ve bilgilendirme yapılmamıştır. Çalışmada annelerin sekiz hafta süresince belirli ölçütler doğrultusunda seçilen nitelikli kitapları çocuklarına okumalarının çocuklarının erken okuryazarlık becerileri üzerindeki etkisini incelemek hedeflenmiştir.

Müdahale çalışmaları için seçilen kitapların özelliklerinin önemi alan yazındaki çalışmalarda vurgulanmıştır. Araştırmada resimli kitapların seçiminde çeşitli ölçütler kullanılmıştır. Ölçütler şunlardır: (1) Çocukların yaş ve gelişimine uygun, ilgi duydukları kitaplar: Çocuklar için ne tür kitap seçileceği, çocukların hangi kitap türlerini tercih etme eğiliminde oldukları düşünülmelidir. Çünkü seçilen kitaplar çocukların katılım ve okuma motivasyonları üzerinde etkilidir ve okuma etkinliğinden daha fazla fayda sağlanması desteklenmiş olur (McNair, 2011). Yine Bus (2001), çocuğun okumaya ilgisinin kitap okuma deneyiminin doğası ile nasıl desteklenebileceğini incelemiştir. Anne-baba, çocuğa "çocuğun dünyası ile kitabın dünyası arasındaki uyuşmazlık" arasında bağ kurarak okunmasının çocuklara eğlenceli okuma deneyimi sunduğunu, çocuğun ilgisini arttırdığını belirtmiştir. (2) Yazı farkındalığını destekleyen kitaplar. Justice, Pullen ve Pence (2008) erken okuryazarlık becerilerini destekleyen kitap okuma çalışmalarında yazı farkındalığını destekleyen özellikte kitaplar seçilmesi gerektiğini vurgulamışlardır. Kitapların resimlendirme, içerik ve fiziksel özellikler bakımından nitelikli olmasına dikkat edilmiş, özellikle yazı farkındalı̆̆ı ve sözcük bilgisini destekleyen kitaplar seçilmeye çalışılmıştır. Kitaplarda farklı yazı tipleri ve punto boyutları ile yazılmış harf veya sözcükler, belirgin biçimde harflerin sayfada yer alması, farklı renkte büyük olması, metin balonlarında bazı ifadelerin gösterilmesi veya kafiye ve ses tekrarının kullanılması gibi özellikler bulunmaktadır. (3) Aşina olunmayan kitaplar; kitap seçiminde üzerinde durulan bir diğer konu ise çocuk ve annelerin daha önceden bilmediği kitaplar olmasıdır. Phillips ve McNaughton (1990) yaptıkları çalışmada kitabı okuyan kişinin kitaba aşina olup olmaması okuma etkinliğinin içeriğini değiştirebildiğini saptamışlardır. Morrow (1988) yaptığı araştırmada tanıdık-aşina bir kitabı okurken, okuyan yetişkinin bilmediği bir kitaptan daha çok bir yazı ve hikaye yapısı hakkında konuştuğunu saptamıştır.

Yukarıda belirtilen tüm bu ölçütler düşünülerek çalışma için kitaplar belirlenmiştir. Çalışma sonucunda tüm anneler düzenli olarak çocuklarına kitap okumuşlardır. Sekiz haftalık okuma uygulaması için ön test ve son test olarak uygulanan "Erken Çocukluk Dönemi Yazı Farkındalığı Kontrol Listesi" nin "Kitap ve yazı düzeni", "Harfler" ve "Yazı" boyutlarında istatistiksel olarak anlamlı bir farklılık olmadığı, buna karşın "Sözcük" boyutu ve "Genel toplam" puanlarında anlamlı farklılıklar olduğu saptanmıştır. "Sözcük" boyutu ve "Genel Toplam" puanlarındaki artış için hesaplanan etki büyüklüğü orta etkinin üstünde bulunmuştur. Başka bir deyişle annelerin ev ortamında çocuklarına sadece düzenli nitelikli çocuk kitapları okuduğunda bile çocukların yazı farkındalığı becerilerinde artış olduğu saptanmıştır.

Yapılan çalışmanın sonuçlarından biri, okul öncesi dönemde çocuklara herhangi bir okuma tekniği 
uygulamadan da düzenli kitap okumanın faydalı olduğudur. Yetişkinlerin çocuklara kitap okuması onların kitapta geçen farklı cümleler içinde yeni kelimeler duymalarını sağlamaktadır. Kelime çeşidi açısından zengin kitaplar (kalem, kitap gibi cins isimler ile sözcük dağarcığını geliştiren kelimeleri de barındıran), bunu sağlamada önemlidir. Ayrıca kitaplar genellikle aynı kelimeleri farklı gramer yapılarında kullanarak çocuklara kelimelerin farklı bağlamlarda nasıl kullanıldığına dair bilgiler sunmaktadır. Kitap metinleri yalın ve kısa cümlelerden oluştuğundan günlük konuşma diline nazaran daha az kelime sunmaktadır (Dickinson ve Tabors 2001'den akt. Dickinson, Griffith, Golinkoff ve Hirsh-Pasek, 2012) ve bu sebeple kitapta geçen kelimelerin günlük konuşmalara nazaran daha geniş yelpazede çocuklar tarafından kullanılmasına olanak vermektedir. Çalışma sonuçlarına paralel olarak kitap okuma sırasında çocukların sözcük bilgileri doğal olarak desteklenmektedir.

Bus ve diğerleri (1995) paylaşımlı hikaye kitabı okunmasının, küçük çocukların yazılı dilin kurallarını öğrenmelerinde etkili olduğunu ve dolayısıyla kitap okunmasının çocuklar için yazı hakkında bilgi edinmelerinde kolay ve etkili bir yol olduğunu belirtmişlerdir. Bu çalışmada "Harfler" alt boyutunda ön test ve son test arasında anlamlı farklılık bulunmamıştır. Benzer olarak yapılan çalışmalar çocukların genellikle kitap okunurken harflere dikkat etmediğini göstermiştir (Evans ve Saint-Aubin, 2005; Justice, Skibbe, Canning ve Lankford, 2005). Ancak çocuklar yaşları arttıkça kitaptaki yazılara olan ilgileri artmaktadır (Roy-Charland, Saint- Aubin ve Evans, 2007). Bu sebeple yazı farkındalığı becerileri de desteklenmelidir. Justice ve Ezell (2002) yetişkinlerin çocuklara etkileşimli tekniklerle kitap okurken özellikle sözcük bilgisi ve ses bilgisel farkındalık becerilerini desteklemeye çalıştıklarını, yine yetişkinlerin özellikle hikaye metnini kavranmasına öncelik verdiklerini bulmuşlardır. Ebeveynlerde okuma sırasında yazı farkındalığını desteklediklerinde bu bileşenlerin önüne geçeceği endişesi olduğunu belirtmişlerdir.

Yapılan çalışmada ön test ve son test değerlendirmeleri sonucunda çocukların aldıkları "Genel Toplam" puanlarda yazı farkındalığı becerilerinin arttığı görülmüştür. Mol, Bus ve De Jong (2009) yaptıkları metaanaliz çalışmasında müdahaleli kitap okumanın çocukların dil ve okuryazarlık gelişimini desteklediği hipotezinden yola çıkarak, 31 deneysel çalışmayı ele almışlar ve etkileşimli kitap okuma tekniğinin çocukların erken okuryazarlık becerileri üzerindeki etkisini incelemişlerdir. Sonuçlar, çocukların sözel dilin yanı sıra yazı bilgilerinin de okuma oturumları öncesi, sırası ve sonrasında arttığını göstermiştir. Sözel dil becerilerindeki büyümenin yaklaşık \%6'sı, etkileşimli okuma müdahalesi ile açıklanmıştır (r=.25). Çünkü etkileşimli kitap okuma özellikle çocukların sözel dil becerilerini ve kelime haznelerini destekleyen müdahaleleri kapsadığından bu sonucun çıkması muhtemeldir. Araştırma sonucunda ifade edici sözcük becerilerinin (kelime haznesi) \%8'ini açıklayan orta derecede bir etki büyüklügü bulunmuştur ( $\mathrm{r}=.28)$. Araştırmanın ilginç sonuçlarından biri de aynı okuma programında yetişkinler okuma sırasında yazı farkındalığını destekleme teknikleri konusunda eğitilmemiş olsalar da okul öncesi çocukların alfabetik bilgisindeki varyansın \%7'si interaktif okuma programı ile açıklanabilir. Çocuklar yaşları arttıkça yazıya ilgileri arttı̆̆ından herhangi bir teknik kullanılmasa da yazı farkındalığı okuma sırasında desteklenebilmektedir.

Yine bu çalışmada okuma uygulamasının yazı farkındalığını desteklemesine sebep olarak seçilen kitapların özellikle yazı farkındalığını destekleyecek türde kitaplar olması düşünülebilir. Benzer olarak Justice ve Lankford (2002) alternatif olarak, hikaye kitabının kendisi yazı farkındalığını destekler nitelikte olduğunda (farklı yazı tipleri ve punto boyutları ile yazılmış harf veya sözcükler, belirgin biçimde harflerin sayfada yer alması, farklı renkte büyük olması, metin balonlarında bazı ifadelerin gösterilmesi veya kafiye ve ses tekrarının kullanılması gibi) çocuktaki yazı bilgisi ve yazı farkındalığını artırabildiğini belirtmişlerdir. Mol ve diğerleri (2009) yaptıkları çalışmada, inceledikleri müdahale çalışmalarında kullanılan hikaye kitaplarının yazı farkındalığı açısından nasıl türde olduklarından bahsedilmediğine dikkat çekmişlerdir. Ancak müdahale çalışmaları için seçilen kitaplar özellikleri büyük önem taşımaktadır. Yapılan çalışmanın amacına hizmet edecek özellikte kitaplar seçilmesi gerektiği müdahale araştırmalarında vurgulanmıştır (Justice ve diğerleri, 2008; Roy-Charland ve diğerleri, 2007).

Alan yazında planlanan çalışmalarda okunan kitaplara aşina olma durumu ve okuma tekrar sayısı da önem taşımaktadır. Çalışmada her kitabın haftada 2 kez okunması istenmiştir. Çocukların kitap okuma 
sırasında yazı hakkında ne kadar öğrendiklerini yetişkinlerin sözel olarak yazıya dikkat çekme derecesine ve kitapların özelliklerine bağlı olduğunu göstermektedir. Çocukların yaşı arttıkça kitap okuma sırasında hikayeyi daha iyi kavradıklarından kitaptaki harf ve yazılara dikkat edebilirler.

Bir diğer konu ise aynı kitabın okunma sayısıdır. Bir hikayenin tekrar tekrar okunması nedeniyle hikaye içeriğine aşina olmak, çocukların dikkatini metnin diğer özelliklerine kaydırmak için yeni fırsatlar yaratabilir. Kitap okuma sırasında kitabın içeriği hakkında konuşmak, ebeveynlerin çocuklarına okurken yaptıkları en yaygın yorum türüdür. Bununla birlikte, okuma etkileşimleri sırasında meydana gelen konuşma türü, bir çocuğun veya ebeveynin kitabın okunmasına ne kadar aşina olduğuna bağlı olarak değişebilir. Örneğin, Phillips ve McNaughton (1990), ebeveyn-çocuk kitap okuma etkileşimleri sırasında ebeveynin konuşmasının ilk olarak hikaye metninin anlamına odaklandığını, ancak tekrarlanan okumalarda ise ebeveynlerin çocuklarına hikaye ile ilgili tahminler ve çıkarımlar yapmalarını istemeye başladığını tespit etmiştir.

Alan yazında çocukların erken okuryazarlık becerilerinin ev ortamında desteklenmesinin kuramsal temelleri Bronfenbrenner'in (1979) ekolojik modeline dayanmaktadır (akt. Greenwood, Hutton, Dudley ve Horowitz-Kraus, 2019). Bu modele göre dil gelişimi için ekolojik model çocuğun dil becerilerinin desteklenmesinde çocukla kurulan ilişkiye bağlıdır. Genişletilmiş Bronfenbrenner modeli, ev okuryazarlık ortamının yetersiz olması, yani annenin düşük sosyo-ekonomik düzey gibi sebeplerden dolayı okuma yazma kabiliyetinin zayıf olması durumunda annelerin çocuklarının erken okuryazarlık becerilerini daha az desteklediği, daha az kitap okudukları, eğitimin kalitesi ve katılımla ilişkilendirileceğini göstermektedir (Horowitz-Kraus, Hutton, Philean ve Holland, 2017). Kısaca çocuklara kitap okunması ebeveynlerin ev ortamında çocuklarının gelişimlerini desteklemelerini ve çocuk ile ebeveyn arasında olumlu etkileşim kurulmasını sağlamaktadır. Yapılan çalışmalar ev ortamında ebeveynlerin çocuklarına kitap okumalarının çocukların erken okuryazarlık becerileri üzerinde olumlu etkileri olduğu yönündedir. Lonigan (1994) ile Ezell ve Justice (2005) sosyoekonomik düzey, geçmiş yaşantı veya mizacı dikkate almaksızın okul ve ev ortamında yapılan paylaşımlı kitap okuma programlarının çocukların okuma gelişimleri için fayda sağlayacaklarını savunmuşlardır.

Kitap okuma, bilişsel kontrol ve dil becerilerine dayanan edinilmiş bir beceridir. Son yıllarda küçük çocuklara kitap okumanın dil gelişimi ve erken okuryazarlık becerileri dışında beyindeki etkileri üzerine de çalışmalar yürütülmektedir (Grenwood ve diğerleri, 2019; Hutton ve diğerleri, 2015; Hutton ve diğerleri, 2017). Ev ortamında okul öncesi çağdaki çocuklara kitap okuma sırasında çocukların parietal-temporaloksipital lobları aktivasyonları ile hikaye dinleme, zihinsel imgelem ve hikayeyi anlamak için korteks desteklenmesi arasında pozitif korelasyon olduğu saptanmıştır. Raikes ve diğerlerinin (2006) yaptığı çalışma, ilk üç yılda bebeklere anneleri tarafından kitap okunmasının beyinlerinin aktivasyonlarını olumlu etkilediğini desteklemektedir.

Sonuç olarak çocuklara ebeveynleri tarafından ev ortamında düzenli ve çocukların gelişimlerine uygun nitelikli kitap okunması üzerinde durulması gereken önemli bir konudur. Özellikle yazı farkındalığı becerilerinin doğal olarak desteklenmesi için çocuklara kitap okunması gerekmektedir.

Yürütülen çalışma orta sosyo-ekonomik düzeydeki 20 aile ile sınırlıdır, çalışmada kontrol grubu yer almamaktadır, izleme testi yapılmamıştır ve ailelere okuma konusunda bir eğitim verilmemiştir. İleriki çalışmalar farklı sosyoekonomik düzeydeki aileler ile deney ve kontrol gruplu deneysel araştırmalar deseninde tasarlanabilir. Bu tür uygulamaların etkisinin ne derecede kalıcı olduğunu incelemek amacıyla son test sonrası izleme testi yapılabilir. Ebeveynlere farklı kitap okuma teknikleri hakkında verilen eğitimlerin benzeri yaş grubundaki ve daha küçük çocukların yazı farkındalığı becerileri üzerindeki etkisi incelenebilir.

\section{Yazar(lar)ın Beyanı}

Araştırmacıların katkı oranı beyanı: Araştırmacılar çalışmaya eşit oranda katkı yapmışlardır.

Çatışma beyanı: Araştırmada herhangi bir çıkar çatışması söz konusu değildir.

Destek ve teşekkür: Bu çalı̧ma, Balıkesir Üniversitesi tarafindan desteklenmiştir, BAP Proje No: 2016/0046. 


\section{Kaynaklar}

Adalı, B. (2011). Arkadaşım Papi. İstanbul: Yapı Kredi Yayınları.

Altıparmak, S. (2010). Parental perceptions on emergent literacy in early childhood year (Yayınlanmamış yüksek lisans tezi). Orta Doğu Teknik Üniversitesi, Ankara.

Arıcı, M. ve Tüfekci Akcan, A. (2019). Okul öncesi dönemde anne-çocuk birlikte hikaye kitabı okuma davranışlarının incelenmesi. Yaşadıkça Ĕ̆itim, 33(1), 100-120. doi: 10.33308/26674874.201933195

Burgess, S. R., Hecht, S. A. ve Lonigan, C. J. (2002). Relations of the home literacy environment (HLE) to the development of reading related abilities: A one-year longitudinal study. Reading Research Quarterly, 37(4), 408426. doi:10.1598/RRQ.37.4.4

Bus, A. G. (2001). Joint caregiver-child storybook reading: A route to literacy development. S. B. Neuman ve D. K. Dickinson (Ed.) Handbook of early literacy research (s. 179-191) içinde. New York: Guilford Press.

Bus, A. G., Van IJzendoorn, M. H. ve Pellegrini, A. D. (1995). Joint book reading makes for success in learning to read: A meta-analysis on intergenerational transmission of literacy. Review of Educational Research, 65(1), 1-21. doi: 10.3102/00346543065001001

Cengiz, Ö. (2013). Türk annelerin çocuklarına kitap okurken kullandıkları dil. Edebiyat Fakültesi Dergisi, 30(1), 97114.

Chomsky, C. (1972). Stages in language development and reading exposure. Harvard Educational Review, 42(1), 133. doi: 10.17763/haer.42.1.h781676h28331480

Cook, T. D. ve Campbell, D. T. (1979). Quasi-experimentation: Design and analysis issues for field settings. Boston: Houghton Mifflin.

Coyne, M. D., McCoach, D. B. ve Kapp, S. (2007). Vocabulary intervention for kindergarten students: Comparing extended instruction to embedded instruction and incidental exposure. Learning Disability Quarterly, 30(2), 7488. doi: $10.2307 / 30035543$

Çelebi Öncü, E. (2016). Etkileşimli kitap okumanın beş-altı yaş çocuklarının sosyal durumlara yaklaşımlarına etkisinin incelenmesi. Ana Dili Ĕ̆itimi Dergisi, 4(4), 489-503.

DeLaCova, A. (2003). Prompting parent involvement in preschool children's early literacy development (Yayınlanmamış yüksek lisans tezi). The Florida State University College of Human Sciences, Tallahassee, Florida.

De Temple, J. ve Snow, C. E. (2003). Learning words from books. A. van Kleeck, S. A. Stahl ve E. B. Bauer (Ed.) Center for Improvement of Early Reading Achievement, CIERA. On reading books to children: Parents and teachers (s. 16-36) içinde. Mahwah, NJ: Erlbaum.

Dickinson, D. K., Griffith, J. A., Golinkoff, R. M. ve Hirsh-Pasek, K. (2012). How reading books fosters language development around the World. Child Development Research, 2012, 1-15. doi:10.1155/2012/602807

Ergül, C., Sarıca, A. D., Akoğlu, G. ve Karaman, G. (2017). The home literacy environments of Turkish kindergarteners: Does SES make a difference? International Journal of Instruction, 10(1), 187-202. doi: 10.12973/iji.2017.10112a

Evans, M. A. ve Saint-Aubin, J. (2005). What children are looking at during shared storybook reading: Evidence from eye movement monitoring. Psychological Science, 16(11), 913-920. doi:10.1111/j.1467-9280.2005.01636.x

Ezell H. K. ve Justice L. M. (2005). Shared storybook reading. Baltimore, MD: Brooks Publishing.

Greenwood, P., Hutton, J., Dudley, J. ve Horowitz-Kraus, T. (2019). Maternal reading fluency is associated with functional connectivity between the child's future reading network and regions related to executive functions and language processing in preschool-age children. Brain and Cognition, 131, 87-93. doi:10.1016/j.bandc.2018.11.010 
Hammer, C. S., Miccio, A. W. ve Wagstaff, D. A. (2003). Home literacy experiences and their relationship to bilingual preschoolers' developing english literacy abilities: An initial investigation. Language, Speech, and Hearing Services in Schools, 34(1), 20-30. doi: 10.1044/0161-1461(2003/003)

Hammer, C. S., Nimmo, D., Cohen, R., Clemons, H. ve Achenbach, A. (2005). Book reading interactions between African American and Puerto Rican Head Start children and their mothers. Journal of Early Childhood Literacy, 5(3), 195-227. doi: 10.1177/1468798405058683

Horowitz-Kraus, T., Hutton, J., Philean, K. J. ve Holland, S. K. (2017). Better maternal reading fluency is related to stronger functional connectivity in future reading networks in preschool children. San Francisco: Cognitive Neuroscience Society.

Hutton, J. S., Horowitz-Kraus, T., Mendelsohn, A. L., DeWitt, T., Holland, S. K. ve the C-MIND Authorship Consortium (2015). Home reading environment and brain activation in preschool children listening to stories. Pediatrics, 136(3), 466-478. doi: 10.1542/peds.2015-0359

Hutton, J. S., Phelan, K., Horowitz-Kraus, T., Dudley, J., Altaye, M., DeWitt, T. ve Holland, S. K. (2017). Story time turbocharger? Child engagement during shared reading and cerebellar activation and connectivity in preschool-age children listening to stories. Plos One, 12(5), 1-50. doi: 10.1371/journal.pone.0177398

Işıkoğlu Erdoğan, N. (2016). Erken çocukluk döneminde çocuk-ebeveyn birlikte okuma etkinliklerinin incelenmesi. Kastamonu Ĕ̆itim Dergisi, 24(3), 1071-1086.

Işıkoğlu Erdoğan, N., Atan, A., Asar, H., Mumcular, F., Yüce, A., Kiraç, M. ve Kilimlioğlu, Ç. (2016). Ebeveyn ve öğretmenlerin birlikte hikâye okuma etkinliklerinin incelenmesi. İlköğretim Online, 15(1), 125-135. doi:10.17051/io.2016.05211

Işıtan, S. ve Akoğlu G. (2016). Yazı farkındalığı becerilerinin resimli çocuk kitabı aracıllı̆ı̆la değerlendirilmesi: Güvenirlik ve geçerlik çalışması. Turkish Studies -International Periodical for the Languages, Literature and History of Turkish or Turkic, 11(3), 1333-1352. doi: 10.7827/TurkishStudies.9111

Justice, L. M. ve Ezell, H. K. (2002). Use of storybook reading to increase print aware-ness in at-risk children. American Journal of Speech-Language Pathology, 11(1), 17-29. doi:10.1044/1058-0360(2002/003)

Justice, L. M. ve Lankford, C. (2002). Preschool children's visual attention to print during storybook reading: Pilot findings. Communication Disorders Quarterly, 24(1), 9-19. doi: 10.1037/0012-1649.44.3.855

Justice, L. M., Pullen, P. C. ve Pence, K. (2008). Influence of verbal and nonverbal references to print on preschoolers' visual attention to print during storybook reading. Developmental Psychology, 44(3), 855-866. doi: 10.1037/0012-1649.44.3.855

Justice, L. M., Skibbe, L., Canning, A. ve Lankford, C. (2005). Pre-schoolers, print and storybooks: An observational study using eye movement analysis. Journal of Research in Reading, 28(3), 229-243. doi:10.1111/j.14679817.2005.00267.x

Kotaman, H. (2008). Türk ana babalarının çocuklarının eğitim öğretimlerine katılım düzeyleri. Uludağ Üniversitesi Eğitim Fakültesi Dergisi, 21(1), 135-149.

Lonigan, C. J. (1994) Reading to preschooler exposed: Is the emperor really naked? Developmental Review, 14(3), 303-323. doi: 10.1006/drev.1994.1011

Lonigan, C .J. (2004). Emergent literacy skills and family literacy. Wasik B. H. (Ed.), Handbook of family literacy (s.57-82) içinde. Mahwah, NJ: Lawrence Erlbaum Associates.

Lopez, L. M. (2005). A look into the Homes of Spanish-Speaking preschool children. Cohen, J., McAlister, K. T., Rolstad, K. ve MacSwan, J. (Ed.), ISB4: Proceedings of the 4th international symposium on bilingualism (s. 13781383) içinde. Somerville, MA: Cascadilla Press.

McNair, J. C. (2011). "It was like a book buffet!" Parents and children selecting African American children's 
literature together. The Journal of Negro Education, 80(2), 163-175.

Mol, S. E., Bus, A. G. ve De Jong, M. T. (2009). Interactive book reading in early education: A tool to stimulate print knowledge as wellas oral language. Review of Educational Research, 79(2), 979-1007. doi:10.3102/0034654309332561

Morrow, L. M. (1988). Young children's responses to one-to-one story readings in school settings. Reading Research Quarterly, 23(1), 89-107. doi: 10.2307/747906

Morrow, L. M. ve Gambrell, L. B. (2002). Literature-based instruction in the early years. S. B. Neuman ve D. K. Dickinson (Ed.), Handbook of early literacy research (s. 348-360) içinde. Spring Street, NY: Guilf.

Needlman, R, Fried, L. E., Morley, D. S. , Taylor, S. ve Zuckerman, B. (1991). Clinic-based intervention to promote literacy. A pilot study. Am J Dis Child, 145(8), 881-884. doi: 10.1001/archpedi.1991.02160080059021

Needlman, R., Toker, K. H., Dreyer, B. P., Klass, P. ve Mendelsohn, A. L. (2005). Effectiveness of a primary care intervention to support reading aloud: A multicenter evaluation. Ambulatory Pediatrics, 5(4), 209-215. doi:10.1367/A04-110R.1

Okuyucu-Akdaş, E. ve Deniz, Ü. (2015). Anasınıfına devam eden çocukların kitap ile birlikteliklerine ve ailelerinin özelliklerine göre okuma olgunluklarının incelenmesi. Uluslararası Türk Ĕ̆itim Bilimleri Dergisi, 2015(4), 15-27.

Özbek Ayaz, C. (2015). Ailelerin, okul öncesi dönemdeki çocuklarının okuryazarlık becerilerini desteklemek için kullandıkları okuryazarlık uygulamalarının incelenmesi: Tekirdă̆ ili örneği (Yayımlanmamış yüksek lisans tezi). Çanakkale Onsekiz Mart Üniversitesi, Çanakkale.

Özbek Ayaz, C., Güleç, H. ve Şahin, Ç. (2017). Ailelerin, çocuklarıyla birlikte gerçekleştirdikleri okuma aktivitelerinin düzeyini belirleme. Ahi Evran Üniversitesi Kırşehir Eğitim Fakültesi Dergisi (KEFAD), 18(1), 1-19.

Phillips, G. ve McNaughton, S. (1990). The practice of storybook reading to preschool children in mainstream New Zealand families. Reading Research Quarterly, 25(3), 196-212. doi: 10.2307/748002

Polat Unutkan, Ö. (2006). Anne babaların kitap okumaya ilgilerinin çocukların dil gelişimi açısından ilköğretime hazır bulunuşluğuna etkisi. Kazım Karabekir Eğitim Fakültesi Dergisi, 13, 285- 293.

Raikes, H., Pan, B. A., Luz, G., Tamis-Lemonda, C. S., Brooke-Gunn, J., Constantine, J. ve Rodriguez, E. T. (2006). Mother-child bookreading in low-income families: Correlates and outcomes during the first three years of life. Child Development, 77(4), 924-953. doi: 10.1111/j.1467-8624.2006.00911.x

Roberts, J., Jurgens, J. ve Burchinal, M. (2005). The role of home literacy practices in preschool children's language and emergent literacy skills. Journal of Speech, Language, and Hearing Research, 48(2), 345-359. doi: 10.1044/1092$4388(2005 / 024)$

Rodriguez, E. T., Tamis-LeMonda, C. S., Spellmann, M. E., Pan, B. A., Raikes, H., Lugo-Gil, J. ve Luze, G. (2009). The formative role of home literacy experiences across the first three years of life in children from lowincome families. Journal of Applied Developmental Psychology, 30(6), 677-694. doi:10.1016/j.appdev.2009.01.003

Rosenkoetter, S. ve Barton, L. (2002). Bridges to literacy: Early routines that promote later school success. Bridges to literacy: Early routines that promote later school success. Zero to Three, 22(4), 33-38.

Roy-Charland, A., Saint-Aubin, J. ve Evans, M. A. (2007). Eye movements in shared book reading with children from kindergarten to Grade 4. Reading and Writing, 20(9), 909-931. doi:10.1007/s11145-007-9059-9

Schickedanz, J. A. ve McGee, L. M. (2010). The NELP report of shared story reading interventions (Chapter 4): Extending the story. Educational Researcher, 39(4), 323-329, doi: 10.3102/0013189X10370206

Sharif, I., Reiber, S. ve Ozuah, P. O. (2002). Exposure to Reach Out and Read and vocabulary outcomes in inner city preschoolers. Journal of the National Medical Assocation, 94(3), 171-177.

Smith, S. S. ve Dixon, R. G. (1995). Literacy concepts of low-and middle-class four-year-olds entering preschool. 
The Journal of Educational Research, 88(4), 243-253. doi: 10.1080/00220671.1995.9941305

Snow, C. E., Burns, S. ve Griffin P. (1998). Preventing reading difficulties in young children. Washington, DC.: National Academy Press.

Storch, S. A. ve Whitehurst, G. J. (2001). The role of family and home in the developmental course of literacy in children from low-income backgrounds. P.R. Britto ve J. Brooks-Gunn (Ed.), New directions in child development: the role of family literacy environment in promoting young children's emerging literacy skills (s.53-71) içinde. San Francisco, CA: Jossey-Bass/Pfeiffer.

Turan, F. ve Akoğlu, G. (2014). Okul öncesi dönemde ev okuryazarlık ortamı ve fonolojik farkındalık becerileri. Hacettepe Üniversitesi Ĕ̆itim Fakültesi Dergisi, 29(3), 153-166.

Vivas, E. (1996). Effects of story reading on language. Language Learning, 46(2), 189-216. doi:10.1111/j.14671770.1996.tb01234.x

Weigel, D. J., Martin, S. S. ve Bennett, K. K. (2006). Contributions of the home literacy environment to preschool aged children's emerging literacy and language skills. Early Child Development and Care, 176(3-4), 357-378. doi:10.1080/03004430500063747

Whitehurst, G. J., Arnold, D. S., Epstein, J. S. ve Angell, A. L. (1994). A picture book reading intervention in day care and home for children from low-income families. Developmental Psychology, 30(5), 679-689. doi:10.1037/0012-1649.30.5.679

Whitehurst, G. J. ve Lonigan, C. (2001). Emergent literacy: Development from prereaders to readers. S. Neuman ve D. Dickinson (Ed.), Handbook of early literacy research (s. 11-30) içinde. New York: Guilford.

Wigfield, A. ve Guthrie, J. T. (1997). Relations of children's motivation for reading to the amount and breadth of their reading. Journal of Educational Psychology, 89(3), 420-432. doi:10.1037/0022-0663.89.3.420

Zeece, P. D. ve Wallace, B. M. (2009). Books and good stuff: A strategy for building school to home literacy connections. Early Childhood Education Journal, 37(1), 35- 42. doi:10.1007/s10643-009-0325-0 


\section{EXTENDED ABSTRACT}

\section{Introduction}

Reading story books to preschoolers supports their early literacy and school readiness skills as well as their receptive and expressive language skills (Ezell and Justice, 2005; Snow, Burns and Griffin, 1998; Storch and Whitehurst, 2001). Burgess, Hecht and Lonigan (2002) found that early literacy skills started to develop especially in the preschool period between the ages of 3-5 and shared/interactive story reading activities at home influence children's reading and language development. Bus, Van Ijzendoorn and Pellegrini (1995), on the other hand, have suggested that in the first 6 years of life, parents' reading a story book with their children (in other words, reading a shared book activities) was associated with academic skills, language development, emerging literacy skills, and future reading success. Morrow and Gambrell (2002) stated that the most important activity to support children's literacy skill in preschool period was story book reading to children both at home and in school. Early literacy skills can be supported not only in the school environment but also in the home environment. The aim of this study was to investigate the effect of home based family book reading activities on print awareness of young children. In this study, families have not received any training and information about book reading techniques. It was aimed to examine to the extent to which children's early literacy skills can be supported through regular book reading activities at home.

\section{Method}

In the present study, one group pretest - posttest pre- experimental design was used to investigate the effect of home based family reading activities on print awareness skills of young children. The convenience sample of the study consisted of 20 preschoolers ( 7 boys and 13 girls) and their mothers all from middle socioeconomic status in Balıkesir Province. In this study, face to face interviews were conducted with mothers to inform them about the purpose of the study. The mothers voluntarily participated in the study and signed the consent form. The mean age of the mothers was $34.4 \pm 4.9$ years and the mean age of the children was $54.0 \pm$ 11.7 months. Fifteen children enrolled in preschool and 5 children did not receive preschool education. "Family Information Form" was used to collect demographic data from parents. "Early Childhood Print Awareness Checklist" was used to assess children's print awareness skills in pre- and post-test in a quiet and comfortable home environment. A total of 8 picture books were distributed to the parents. These books were selected by the researchers based on the following criteria: (1) Story books that are appropriate for children's age, developmental level and interest, (2) Story books that support print awareness skills, (3) Story books that mothers and children are not familiar with. Mothers were asked to read a total of 8 picture books twice a week. The mothers were asked to record their reading dates and times on the Reading Record Form. Mothers did not receive any training or information about the methods of reading books to young children.

\section{Results}

In this study descriptive statistics, dependent sample T-test and Wilcoxon test were used for data analysis. The results of the study indicated that there was an increase in the scores of children from pre-test to post-test in all sub-dimensions of Early Childhood Print Awareness Checklist. However, the observed increase in the "book and writing order" and "writing" dimensions was no statistically significant. Nevertheless, the observed increases in the scores obtained in the "Word" dimension and "General Total Scores" were statistically significant. The calculated effect size for these significant increases were found to be above the moderate effect.

\section{Conclusion}

The results demonstrated that regularly reading quality picture story books at home, even without providing parents a training to do so, increases children's print awareness skills. This finding is noteworthy as it highlights the importance of the naturally occurring book reading activities at home on young children's early literacy skills. Such activities may also have potentials to promote positive interaction between the child and the parent thereby providing ample opportunities to support language development. Experimental 
studies focusing on the effects of training programs about different reading techniques provided to parents on their children's early literacy skills were suggested. Further studies should also include more diverse samples of parents and children and includes children younger than 36 months. 